\title{
The importance of physical and biotic scaling to the experimental simulation of a coastal marine ecosystem
}

\author{
K. T. Perez 1 , G. M. Morrison ${ }^{1}$, N. F. Lackie ${ }^{1}$, C. A. OviatT' ${ }^{2}$, \\ S. W. Nixon ${ }^{2}$, B. A. Buckley ${ }^{2} \&$ J. F. Heltshe ${ }^{3}$ \\ ${ }^{1}$ Environmental Protection Agency; Narragansett, Rhode Island, USA, \\ ${ }^{2}$ Graduate School of Oceanography, University of Rhode Island; \\ Narragansett, Rhode Island, USA, \\ and \\ ${ }^{3}$ Department of Computer Science and Experimental Statistics, \\ University of Rhode Island; Kingston, Rhode Island, USA
}

\begin{abstract}
A marine microcosm, consisting of a pelagic phase interacting with a benthic phase, is described. Variations in water turnover, turbulence, incident radiation and ratio of pelagic volume to benthic surface area are shown to have significant effects on the behavior of these microcosms. It is argued that the inclusion and accurate simulation of appropriate levels of these variables is important in microcosm studies designed to study the dynamics of natural systems.
\end{abstract}

\section{INTRODUCTION}

Ecologists are being asked to develop management strategies for large scale ecosystems. The development of such strategies requires a knowledge of the consequences of local perturbations on the entire ecosystem. However, direct experimentation with large scale natural ecosystems is extremely difficult. First, experimental control and treatment replication is virtually impossible. Second, it is often difficult to manipulate state variables or parameters. Third, control and/or knowledge of disturbances other than those experimentally imposed may be lacking. Finally, even knowing the above constraints, the system is unavailable for experimentation. As a result, the analysis of large scale system behavior is usually confined to indirect approaches.

One such indirect approach is the development of simulation models. The data base and principles from which most models are formulated are usually derived from. individual components of a system. These components are isolated from the total system before the experiments are performed. Such studies assume that the holistic properties of models are similar to the natural system being simulated. A recent study, however, indicated that a complex model developed from isolated components of a lake ecosystem provided limited realistic information (Walters \& Efford, 1972). 
Another indirect approach is the simulation of the large scale system on a smaller scale in the laboratory or sub-area in the field. The reduction of volume (aqueous systems) and other system variables provides investigators with a physically manageable system that lends itself to experimental control and replication. The basic assumption is that the instantaneous mean state for the small scale laboratory system and the natural field system are equivalent. Previous studies have not adequately tested this assumption. The biotic assemblages and scaling of physical variables within such studies have been simple or arbitrary and usually bear no resemblance to the field system. For example, Odum et al. (1963) and Odum \& Chestnut (1970) did not attempt to produce or verify that the composition and densities of flora and fauna employed at the start of the experiment and thereafter in the laboratory systems were at all similar to the large scale field system. Most experimental systems (e.g., Takahashi et al., 1975; Copper \& Copeland, 1974) failed to incorporate and, thus, consider the natural levels and/or rates of physical variables such as turbulence and water turnover.

This study describes an experimental system which attempts to dynamically mimic a large scale marine system on a small scale. We adjusted the various physical and biotic variables to approximate and simulate field conditions. Experimental light, benthic surface area to water volume ratio, water turnover time, and turbulence values were established from emperical field measurements or models of the test area. Each laboratory experiment consisted of adjusting the above variables both singly and in combination about the estimated field levels. Concurrent measurements of biotic structure and function were made in the laboratory systems and the natural system. Comparisons and appropriate statistical tests between the two systems provide a test for the validity of such estimates as well as the roll played by each variable in the natural system.

\section{MATERIAL AND METHODS}

\section{Study area description}

Narragansett Bay is a well mixed, temperate estuary, exhibiting only weak transitory temperature and salinity gradients (Hicks, 1959). The principle influx and eflux of bay water is via the East and West Passages (Fig. 1). A portion of West Passage was selected as the area to be simulated in the laboratory because of its proximity to the laboratory site and minimal spatial heterogeneity, relative to the entire bay. Water used in the study was collected from a dock extending approximately $90 \mathrm{~m}$ into the bay. Tidal action is semi-diurnal, having two highs and two lows per day. Tidal currents in West Passage indicate that water transport above and below the dock during a mean tide will extend roughly to the area indicated in Figure 1 (Spaulding \& Swanson, 1975). This tidal excursion delineates the boundaries of the simulation area. The flushing time of this area is estimated to be less than 35 days, the flushing time for Narragansett Bay (Anonymus, 1959). The mean depth is about $8.6 \mathrm{~m}$ with a mean tidal range of about $1.1 \mathrm{~m}$. The benthic surface area is calculated to be 
$1.5 \times 10^{7} \mathrm{~m}^{2}$ and the water volume $1.3 \times 10^{8} \mathrm{~m}^{3}$. The benthic surface area/water volume ratio (in $\mathrm{m}$ ) is 0.115 . Intertidal surface area comprises only $0.12 \%$ of the total benthic surface area.

The phytoplanktonic biota of Narragansett Bay is generally characterized as a diatom dominated community during the winter months, Skleletonema costatum, Asterionella japonica and Detonula confervacea being the predominate organisms. Dinoflagellates and green algae comprise the most numerous forms during the warmer months (Pratt, 1965).

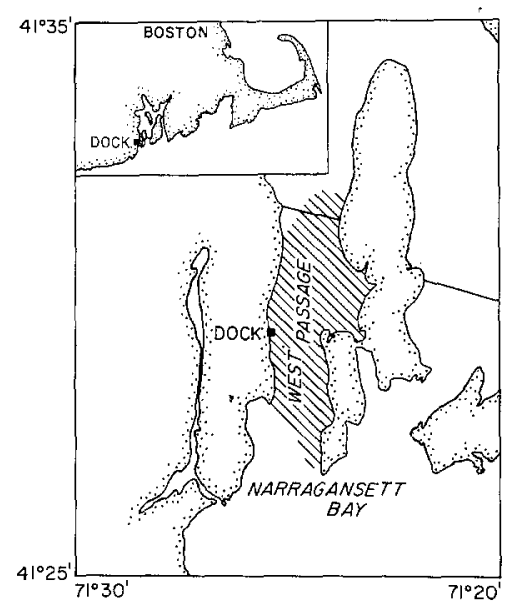

Fig. 1: Location of experimental area, West Passage or Narragansett Bay, Rhode Island

The zooplanktonic organisms also vary with the seasons. During winter and early spring Acartia clausi is numerically superior. Acartia tonsa dominates in the summer and fall. Several other calanoid copepods, harpactids and cyclopoids are usually present along with other transient larval forms. These, however, generally form a minor numerical portion of the zooplanktonic community. The benthic assemblage of the area from which the microcosm samples were collected is characterized as a Nephtys incisa, Nucula proxima, Yoldia limulata community (Hale, 1974).

An intensive preliminary sampling study was conducted to measure the simultaneous vertical and horizontal distribution of phytoplankton, zooplankton densities, chlorophyll $a$ and ammonia levels at six locations in the study area. These data provided an estimate of the structural and functional state of West Passage, the system being simulated. It also enabled us to assess the relationship between our water collection site at the dock and the West Passage.

\section{Experimental system}

The experimental system used to simulate the study area on a reduced scale is shown in Figure 2. It consists of replicate $166 \mathrm{I}$ plastic containers immersed in a 
flow-through seawater trough. Water for the trough was pumped directly from West Passage and thus afforded excellent daily and seasonal temperature reproduction. The experimental tanks were each filled with 1501 of seawater (the pelagic component). This volume was selected because it was small enough to allow sufficient replication but large enough for adequate sampling. The flora and fauna in the pelagic component was limited to organisms that would pass through a $1 \mathrm{~mm}$ nylon screen. Initial tank filling and subsequent water replacement was accomplished by hand bucketing water from the bay to the tanks to avoid biotic damage. Water for initial tank filling and subsequent replacement was collected at mid-tide and was distributed among the tanks in such a manner as to insure a homogeneous distribution of the water and thus, the pelagic biota.

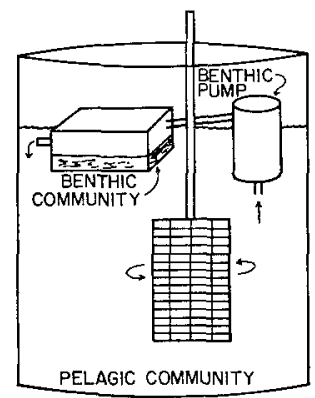

Fig. 2: Experimental system

The benthic component consisted of an opaque $19.5 \mathrm{~cm} \times 9 \mathrm{~cm} \times 24 \mathrm{~cm}$ polyvinylchloride box containing bottom sediment. The benthic box was designed as a functional box corer. The benthic community was collected and held in the microcosms in the same boxes. This provided relatively undisturbed benthic samples but prohibited effective faunal control. Epifauna such as hermit crabs and mud snails were generally removed or at least equalized between treatments. The dimensions of the benthic box were selected so as to provide the same benthic surface area to water volume ratio as that found in the field system. The surface area on other surfaces (e.g., pelagic container) were scrubbed daily so as to prevent the development of fouling communities. The benthic surface area was reduced, in designated experiments, by removing the appropriate fraction with a specifically designed corer leaving the remaining fraction, if any, structurally intact. The benthic boxes were constructed of an opaque material in order to approximate the light incident on the sediment surface. There was no intertidal fraction designed into the benthic component because this comprises such a small percentage of the natural system. Identical regulated water flows across the sediment surfaces were provided by a single control system operating air displacement pumps. This gentle method of water transport eliminated pump damage to the planktonic biota. Mean water flow through the benthic boxes was adjusted to $1.4 \mathrm{~cm}-\mathrm{sec}^{-1}$. This was a low approximation of bottom water flow in the study area $\left(6-67 \mathrm{~cm}-\mathrm{sec}^{-1}\right)$ but was sufficient to eliminate functional gradients across the sediment surface. The 
pumping cycle was $30 \mathrm{sec}$ on and $30 \mathrm{sec}$ off. If one arbitrarily assumes that only the water ranging from zero to $2 \mathrm{~mm}$ above the sediment surface comes in direct contact with the sediment, then the time required for the entire pelagic volume to pass over the sediment surface was a minimum of 6 days. Since no data exists for vertical eddy diffusion rates in the study area, it was not possible to determine whether this time period was too long or too short.

Light for the experimental systems was provided by Westinghouse Cool White fluorescent lamps. Rotation of half-blackened plastic tubes placed over the lamps controlled light intensity. The spectral radiant energy distribution of a standard cool white fluorescent lamp (Bernier, 1962) closely approximates the energy spectrum of the irradiance transmittance for surface coastal water, type nine (Jerlov, 1968). Light duration for the microcosms was regulated by a 24 h clock adjusted weekly to correspond with the natural diurnal light cycle. Ambient surface irradiation data measured in langleys $\cdot \mathrm{h}^{-1}$ was provided by Eppley Labs. Inc., Newport, Rhode Island (USA).

Water turbulence in the pelagic phase was provided by paddles constructed from a plastic grid (12 mm $\times 12 \mathrm{~mm}$ opening size). The paddles were driven by an electric motor connected to all the paddle shafts by a bicycle chain thus producing identical mixing in all tanks. The direction of rotation was automatically reversed every $30 \mathrm{sec}$ to produce a continuous turbulent mixing. The magnitude of turbulence was controlled by the paddle shape, size, and turning rate. Attempts to match the turbulence level in the tanks to that in the field were made by comparing the dissolution rates of hard crystalline sugar balls (Oviatt et al., 1976). In experiments where water turbulence was reduced by removing the paddles, the tanks were not completely stagnant because of the circulation from benthic pumps, water addition, sampling and tank cleaning. It is important to point out that as a result of the configuration of the coupling between the benthic and pelagic phases, the effects of variations in pelagic turbulence on the benthic subsystem were confined to indirect biotic effects realized in the pelagic phase.

The microcosms, were discreetly open systems. The normal water turnover rate in the microcosms was 101 three times a week. The resulting turnover time (35 days) was somewhat greater than that of West Passage but was necessary because of initial manpower restrictions.

The experimental procedure consisted basically of (a) setting up the experimental tanks with water and benthic boxes, (b) measurement of the desired parameters in selected tanks and the dock to establish time zero, pre-treatment levels, (c) imposing treatments, (d) measurements of desired parameters periodically in the microcosms and in West Passage while maintaining the system as described above.

The parameters routinely measured from the pelagic component and considered reliable indicators of change in system structure and function were: phytoplankton identification and enumeration (Utermöhl, 1931); zooplankton identification, enumeration and age structure; chlorophyll (in vivo and extracted) (Strickland \& Parsons, 1968); primary productivity ( ${ }^{14} \mathrm{C}$ uptake) (Strickland \& Parsons, 1968) and ammonia (Solorzano, 1969). Functional measures of the benthic community were ammonia flux and oxygen uptake.

Data analysis was performed using the method of repeated measures (Winer, 
1971). This analysis was chosen because of the time dependency of measurements within tanks. Tests were performed for individual treatment effects and their interaction. Differences between specific treatment means were determined by appropriate t-tests (Snedecor, 1970; p. 349). For those experiments having three different rates and/ or levels for each treatment (variable), it was possible to test whether the form of the response was significantly linear or quadratic. Where appropriate, standard regression techniques were employed; significance was at the $5 \%$ level or less.

Each experiment generally ran for 30 to 35 days. The one exception was the second light experiment ( $\#$ ) which ran for 16 days. The 30 day period was believed to be sufficient time for the tanks to reflect treatment conditions based on the generation time of the phyto- and zooplankton. This also represents nearly one complete water turnover at the normal water replacement rate.

One of the factors not taken into consideration in the establishment and maintenance of the laboratory systems was the influence of storm water runoff and the associated influx of nutrients. The reason for this omission was primarily a lack of a good estimation of the amounts and type of nutrients added to West Passage during rainfall. The microcosms did receive nutrient enriched water following a heavy rainfall through the water exchange process but to a lesser degree than did the natural

Table 1

Treatment conditions and number of replicates for each experiment

\begin{tabular}{|c|c|c|c|c|c|}
\hline $\begin{array}{r}\text { Experiment No. } \\
\text { Season }\end{array}$ & $\frac{1}{1 / 20-2 / 23}$ & $\begin{array}{c}2 \\
2 / 24-3 / 29\end{array}$ & $4 / 6-5 / 6$ & $\begin{array}{c}4 \\
5 / 13-6 / 14\end{array}$ & $\begin{array}{c}5 \\
6 / 29-7 / 15\end{array}$ \\
\hline Number of tanks & 11 & 3 & 20 & 18 & 20 \\
\hline Paddle size & \multicolumn{5}{|c|}{ Number of replicates } \\
\hline (7)- & 11 & 3 & 7 & 9 & 20 \\
\hline 0.5 & - & - & 6 & - & - \\
\hline 0 & - & - & 7 & 9 & - \\
\hline \multicolumn{6}{|l|}{ Water turnover time } \\
\hline (days) $\quad 7$ & $\overline{1}$ & - & 7 & - & $=$ \\
\hline 35 & 11 & 3 & 6 & 18 & 20 \\
\hline 100 & - & - & 7 & - & - \\
\hline \multicolumn{6}{|l|}{$\begin{array}{l}\text { Benthic surface } \\
\text { area }\left(\% \text { of } 169 \mathrm{~cm}^{2}\right)\end{array}$} \\
\hline $0 \%$ & - & - & - & 6 & - \\
\hline $50 \%$ & - & - & - & 6 & - \\
\hline $100 \%$ & 11 & 3 & 20 & 6 & 20 \\
\hline \multirow{7}{*}{$\begin{array}{l}\text { Light regime } \\
\text { (langleys/day) }\end{array}$} & \multicolumn{5}{|c|}{ Average light/number replicates } \\
\hline & $10.5 / 2$ & \multirow{6}{*}{$4.58 / 3$} & \multirow{6}{*}{$6.31 / 20$} & $8.62 / 18$ & $9.89 / 3$ \\
\hline & $6.02 / 2$ & & & & $5.92 / 3$ \\
\hline & $3.56 / 2$ & & & & $3.49 / 3$ \\
\hline & $2.20 / 2$ & & & & $2.15 / 3$ \\
\hline & $0.73 / 1$ & & & & $0.7 / 3$ \\
\hline & $10.5-2.2 / 2$ & & & & $9.89-2.15 / 2$ \\
\hline
\end{tabular}


system. Another factor of unknown importance in which the microcosms varied from the natural system was the fact that water exchange in the field study area occurred at the boundaries of the system whereas exchange water for the microcosms came from the center of the field system.

A series of five experiments starting in January and ending in July were performed (Table 1).

The first experiment was designed to establish the appropriate light regime for our laboratory tanks. If the $8.5 \mathrm{~m}$ water column in the field is uniformly mixed, then a planktonic organism would spend an equal amount of time at each depth and, thus, at each depth specific light regime. Assuming this is true (we have no evidence to think otherwise), then the average light regime received by planktonic organisms in the field is the average light regime for the entire $8.5 \mathrm{~m}$ water column. Similarly, the pelagic biota in our well mixed laboratory tanks would receive the average light regime for the $0.7 \mathrm{~m}$ water column. Thus, the surface light intensity and seasonal photoperiod was adjusted to achieve this average light regime in the laboratory tanks. In West Passage during January the average water column light intensity was 23 langleys-day ${ }^{-1}$; the depth at which this light regime occurred was between 2 and $3 \mathrm{~m}$. Preliminary experiments had shown that average light regimes less than 23 langleysday $^{-1}$ produced algal blooms in the laboratory tanks. As a result, we decided to impose light regimes much less than 23 langleys-day ${ }^{-1}$ in this first experiment, leaving the other variables of turbulence, water turnover and benthic surface area fixed and at levels and/or rates equal to our best field estimates of (Table 1) respectively, so as to establish the average light regime which best tracked W. Passage. The above assumes that the planktonic organisms respond only to the instantaneous light intensity experienced when traveling up and down in a $8.5 \mathrm{~m}$ water column. That is, (1) there is no response to the rate of change in light intensity and (2) the response to surface inhibitory light intensities is a small and therefore, negligible contribution to the total integrated response for the entire water column. To partially test one of these assumptions, at least at one rate of change, replicate tanks were exposed to a fluctuating light regime of 10.5 and 2.2 langleys $\cdot$ day $^{-1}$. The tanks were alternately exposed to 10.5 and 2.2 langleys $\cdot$ day $^{-1}$ for three and two days, respectively.

In Experiment 2, we wanted to determine whether the average light regime found to best follow the dock from the first experiment would follow the dock in a similar fashion when adjusted for seasonal changes in light. The other variables of turbulence, water turnover and benthic surface area were set at rates and/or levels equal to our best field estimates (Table 1 ).

Experiment 3 was factorially designed so as to test the main and interaction effects of different rates of turbulence and water turnover. As indicated in Table 1, three rates were chosen for each variable, thus enabling significance tests for linearity of response. Benthic surface area for all tanks was $169 \mathrm{~cm}^{2}$. The average light regime was adjusted to that found at a specific depth in W. Passage which best tracked the dock in Experiment 1 after adjusting for seasonal changes in light (Table 1).

Experiment 4 was factorially designed so as to test the main and interaction effects of different rates of turbulence and levels of benthic surface area. Turbulence had two different levels, those provided by 0 and 1 stirring paddles while the benthic 
surface area varied from 0,50 and $100 \%$ (100\% was that area, $169 \mathrm{~cm}^{2}$, when divided by the volume of the laboratory pelagic phase equaled the surface area to volume ratio for $\mathrm{W}$. Passage). The entire benthic subsystem i.e., the pump and box core was present and functioning for the $0 \%$ benthic surface area condition. The only element missing was the sediment and associated fauna. The water turnover rate was 35 days over all treatments. As in Experiments 2 and 3, the average light regime was adjusted to that found at a specific depth in W. Passage which best followed the Dock in Experiment 1 after adjusting for seasonal changes in light (Table 1).

Experiment 5 was a repeat of the first experiment during the summer season (see Table 1 for a comparison). Thus, it was possible to determine the systems response to the same light regime during two different seasons.

In summary, the basic objectives of these experiments were to determine (1) whether the laboratory systems response can seasonally follow the natural system, W. Passage of Narragansett Bay, using the best estimates available for various physical and biotic variables and (2) how, after the establishment of a light regime (Experiment 1 ), the variance above and below these estimates of turbulence, water turnover time and benthic surface area influenced the ability of the laboratory systems to follow the natural system.

\section{RESULTS}

\section{Experiment 1}

The response of the laboratory systems to light regimes less than the average light regime for the field water column, 23 langleys $\cdot$ day $^{-1}$ is presented in Figure 3. Light regimes of 10.1 and 6.0 langleys $\cdot$ day $^{-1}$ resulted in large algal blooms and subsequent rapid decreases as compared to the dock. However, lower light regimes of 3.6 and 2.2 langleys $\cdot$ day $^{-1}$ did result in similar concentrations of chlorophyll $a$ and ammonia and algal densities relative to the dock (Fig. 3). A comparison of the means for these variables in tanks receiving 3.6 and 2.2 langleys $\cdot$ day $^{-1}$ are presented in Table 2 . The mean densities of total grazers (all grazing zooplankters and larvae from other phyla) for each light regime were found to be statistically the same (not shown). The mean density of total grazers over all light regimes was found to significantly greater than the dock (Table 2). However, the temporal response of the total grazers was independent of time (regression equation slope was not significantly different from zero assuming a linear model) suggesting that the higher mean value as compared to the dock was the result of elevated densities in the water used for filling the tanks initially. The average langleys $\cdot$ day $^{-1}$ imposed upon the fluctuating 10.2-2.2 tanks was equal to the fixed 5.86 langley $\cdot$ day $^{-1}$ tanks from day 0 to 15 . Using the log transformation of the algal density and concentration of chlorophyll $a$ for both the fixed, 5.86 and the fluctuating, 10.1-2.2 langley $\cdot$ day $^{-1}$ tanks, we tested the equality of slopes of their respective regression lines. They were found to be not significantly different from one another (not shown). Thus, for the rate of change in light regime chosen, the algae averaged the light energy imposed. 
It would appear the assumptions previously indicated for light simulation were incorrect since light regimes less than 23 langleys $\cdot$ day $^{-1}$, the average light for the water column in West Passage for January, resulted in large algal blooms compared to the dock (Fig. 3). The lack of any significant difference between the slopes for algal

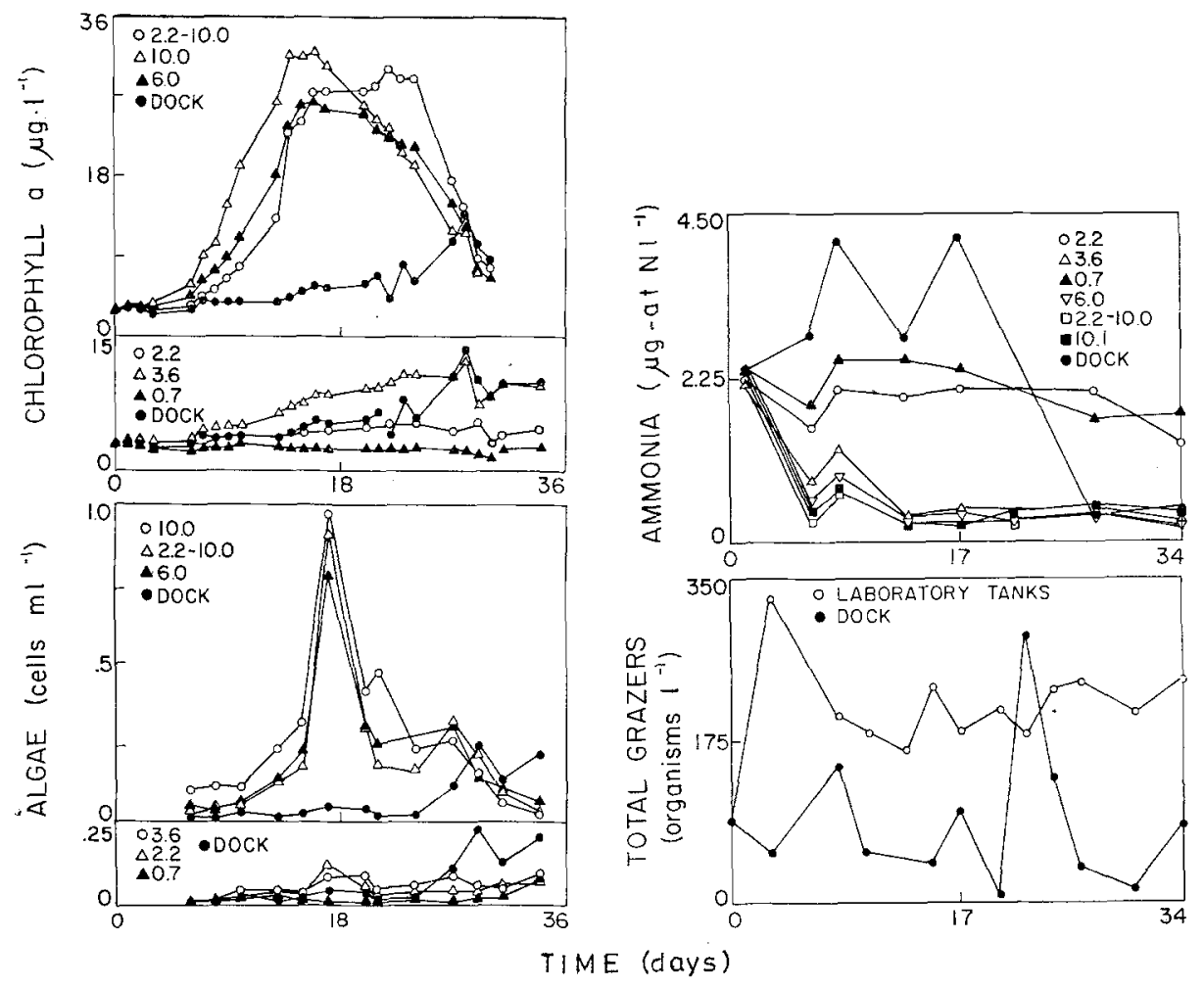

Fig. 3: Effects of different light regimes (langleys day ${ }^{-1}$ ) relative to the dock on the mean daily density and/or concentration of chlorophyll a $\left(\mu \mathrm{g}^{-1}\right)$, algae (cells ml $\left.{ }^{-1}\right)$, ammonia $\left(\mu \mathrm{g}\right.$-at N $\left.{ }^{-1}\right)$ and total grazers (individuals ${ }^{-1}$ ) in laboratory systems

density and concentration of chlorophyll $a$ in the 10-2 and 5.9 langley $\cdot$ day $^{-1}$ tanks showed that the specific rate of change and range of fluctuating light chosen cannot account for rapid algal growths in the 6.0 and 10.2 langley $\cdot$ day ${ }^{-1}$ tanks. In any event, since the mean density of algae in tanks receiving the 3.6 langleys $\cdot$ day $^{-1}$ were statistically the same as the dock (Table 2), we decided to impose this light regime adjusted for season in subsequent experiments. The depth at which 3.6 langleys $\cdot$ day $^{-1}$ would occur during this time of year in W. Passage was computed to be approximately $6.2 \mathrm{~m}$. To obtain the same yet seasonally adjusted light regimes in future experiments, we computed the mean number of langleys $\cdot$ day ${ }^{-1}$ found at $6.2 \mathrm{~m}$ in the field during the season within which the particular experiment was performed (see Table 1 for the light regimes used). Note that at this point in time we had established our best esti- 
Table 2

Comparisons between mean chlorophyll $a\left(\mu \mathrm{g} \cdot 1^{-1}\right)$, algal density (cells $\left.\cdot \mathrm{ml}^{-1}\right)$, total grazers (no. organisms $\cdot 1^{-1}$ ) and water column ammonia ( $\mu \mathrm{g}$ at $\mathrm{N} \cdot \mathrm{l}^{-1}$ ) found in laboratory tanks exposed to 2.20 and 3.56 langleys $\cdot$ day $^{-1}$ for 34 days and the dock during late winter

(Experiment 1)

\begin{tabular}{llll|}
\hline Criteria & \multicolumn{2}{c}{ Tank light regime } & Dock \\
\hline & 2.20 & 3.56 & \\
\hline Chlorophyll a & 4.15 & $7.28^{*}$ & 5.79 \\
Algae & $4.7 \times 10^{3}$ & $5.81 \times 10^{3}$ & $7.94 \times 10^{3}$ \\
Total grazers & $1.90^{* * 207.5^{*}}$ & $0.83^{*}$ & 85.6 \\
Ammonia & & 2.44 \\
$*$ Significantly different $(\alpha=0.05)$ from dock & & \\
$*$ Mean for all light regimes & & & \\
\hline
\end{tabular}

mates for water turnover (35 days), turbulence ( 1 paddle), benthic surface area $\left(169 \mathrm{~m}^{2}\right)$ and light regime (that found at $6.2 \mathrm{~m}$ in the field for a particular experiment).

\section{Experiment 2}

Application of our best estimates for water turnover, turbulence, benthic surface area and the light regime found at $6.2 \mathrm{~m}$ in early spring resulted in significantly higher densities of algae as compared to the dock (Table 3 ). The other variables of chlorophyll $a$, total grazers, ammonia and productivity were statistically equal to the dock.

Table 3

Comparisons between the daily mean chlorophyll a $\left(\mu \mathrm{g} \mathrm{I}^{-1}\right)$, algal density (cells $\left.\cdot \mathrm{ml}^{-1}\right)$, total grazers (organisms $\left.\cdot 1^{-1}\right)$, water column $\mathrm{NH}_{3}\left(\mu \mathrm{g}\right.$ at $\left.\cdot 1^{-1}\right)$ and productivity $\left(\mathrm{mg} \mathrm{C} \cdot \mathrm{h} \cdot 1^{-1}\right)$ found in laboratory tanks with natural depth specific light regime, 35 day water turnover, one paddle turbulence and $169 \mathrm{~cm}^{2}$ benthic surface area and the dock from early spring to midsummer

\begin{tabular}{|c|c|c|c|c|}
\hline $\begin{array}{r}\text { Experiment No. } \\
\text { Season }\end{array}$ & $\begin{array}{c}2 \\
2 / 24-3 / 29\end{array}$ & $4 /{ }^{3}-5 / 6$ & $\frac{4}{5 / 13-6 / 14}$ & $\begin{array}{c}5 \\
6 / 29-7 / 15\end{array}$ \\
\hline $\begin{array}{c}\text { Ta n k s s te m s } \\
\text { Chlorophyll a } \\
\text { Algae } \\
\text { Total grazers } \\
\text { Ammonia } \\
\text { Productivity }\end{array}$ & $\begin{array}{l}9.28 \\
1.02 \times 10^{4 *} \\
177.2 \\
0.48 \\
-\end{array}$ & $\begin{array}{l}12.2^{*} \\
3.46 \times 10^{4 *} \\
43.2 \\
0.39^{*} \\
11.9^{*}\end{array}$ & $\begin{array}{l}8.53 \\
7.68 \times 10^{3 *} \\
11.8 \\
0.37 * \\
6.09\end{array}$ & $\begin{array}{l}8.97 \\
3.14 \times 10^{32} \\
12.2 \\
0.95 \\
5.43\end{array}$ \\
\hline $\begin{array}{l}\text { Dock } \\
\text { Chlorophyll a } \\
\text { Algae } \\
\text { Total grazers } \\
\text { Ammonia } \\
\text { Productivity } *\end{array}$ & $\begin{array}{l}8.30 \\
4.24 \times 10^{3} \\
219.5 \\
0.23 \\
-\end{array}$ & $\begin{array}{l}3.49 \\
1.06 \times 10^{3} \\
38.4 \\
1.33 \\
3.19\end{array}$ & $\begin{array}{l}5.61 \\
1.20 \times 10^{3} \\
20.9 \\
1.13 \\
3.98\end{array}$ & $\begin{array}{l}6.64 \\
3.05 \times 10^{2} \\
10.9 \\
1.51 \\
9.64\end{array}$ \\
\hline $\begin{array}{l}* \text { Significantly differ } \\
* \text { Incubated under la }\end{array}$ & $\begin{array}{l}\mathrm{nt}(\alpha=0.05) \\
\text { poratory light }\end{array}$ & $\begin{array}{l}\text { dock } \\
\text { he }\end{array}$ & & \\
\hline
\end{tabular}




\section{Experiment 3}

The individual means for total grazers, chlorophyll $a$, algae, productivity and ammonia at three levels of turbulence and water turnover are presented in Table 4. A statistical test of turbulence-turnover interaction was found to be nonsignificant for all variables measured. However, the main effects for turbulence and turnover were significant for many of the systems variables. The density of total grazers signicantly increased linearly with decreasing turbulence. This density also significantly increased linearly by the same amount as the rate of water turnover decreased (Table 4).

A partioning of the total grazers into individual mean densities for Acartia clausi adults, juveniles and nauplii showed the same significant differences between these means for different rates of water turnover and turbulence (not shown). The structure (algal density and chlorophyll $a$ ) and function (productivity) of the algal community showed significant linear decreases as turbulence decreased i. e., a response opposite to that found for the total grazers. These results suggest that the observed algal decreases

\section{Table 4}

Comparisons of mean densities, concentrations or rates of total grazers (no. individuals $\cdot 1^{-1}$ ), chlorophyll $a\left(\mu \mathrm{g} \cdot \mathrm{l}^{-1}\right)$, algae (cells $\left.\cdot \mathrm{ml}^{-1}\right)$, productivity $\left(\mathrm{mg} \mathrm{C} \cdot \mathrm{m}^{-3} \cdot \mathrm{h}^{-1}\right.$ ) and ammonia ( $\mu \mathrm{g}$ at $\mathrm{N} \cdot \mathrm{l}^{-1}$ ) for different rates of water turnover (days) and turbulence levels (paddle size)

\begin{tabular}{|c|c|c|c|c|c|}
\hline \multirow[b]{2}{*}{ Criteria } & \multirow[b]{2}{*}{$\begin{array}{l}\text { Water } \\
\text { turnover }\end{array}$} & \multicolumn{3}{|c|}{ Turbulence } & \multirow[b]{2}{*}{$\overline{\mathrm{X}} *$} \\
\hline & & 0 & 0.5 & 1.0 & \\
\hline \multirow{4}{*}{ Total grazers } & 7 & 93.9 & 75.4 & 45.6 & 71.6 \\
\hline & 35 & 145.6 & 87.9 & 43.2 & 92.3 \\
\hline & 100 & 192.6 & 152.9 & 111.7 & 152.4 \\
\hline & $\bar{X}^{*}$ & 144.1 & 105.4 & 66.8 & \\
\hline \multirow[t]{4}{*}{ Chlorophyll a } & 7 & 5.5 & 5.8 & 7.7 & 6.3 \\
\hline & 35 & 4.3 & 9.3 & 12.2 & 8.6 \\
\hline & 100 & 5.2 & 5.3 & 8.4 & 6.3 \\
\hline & $\bar{X}$ & 5.0 & 6.8 & 9.4 & \\
\hline \multirow[t]{4}{*}{ Algae } & 7 & 1169.1 & 7209.0 & 21082.2 & 9986.7 \\
\hline & 35 & 1917.1 & 11735.7 & 34535.0 & 16069.3 \\
\hline & 100 & 1847.1 & 4188.3 & 16885.0 & 7640.1 \\
\hline & $\bar{X}^{*}$ & 1811.1 & 7711.0 & 14930.5 & \\
\hline \multirow{4}{*}{ Productivity } & 7 & 3.3 & 4.2 & 6.6 & 4.7 \\
\hline & 35 & 2.4 & 6.8 & 11.9 & 7.0 \\
\hline & 100 & 3.5 & 4.8 & 7.0 & 5.1 \\
\hline & $\bar{X}^{*}$ & 3.1 & 5.3 & 8.5 & \\
\hline \multirow{4}{*}{ Ammonia } & 7 & 0.30 & 0.24 & 0.27 & 0.27 \\
\hline & 35 & 0.36 & 0.17 & 0.39 & 0.41 \\
\hline & 100 & 0.40 & 0.15 & 0.18 & 0.24 \\
\hline & $\overline{\mathrm{X}} *$ & 0.35 & 0.19 & 0.28 & \\
\hline
\end{tabular}


with lowered turbulence were due to increased grazing pressure resulting from a doubling in density of the total grazers. However, there was no significant difference between the water turnover means for chlorophyll $a$, algal density and productivity (Table 4). To verify this result an analysis of covariance (not shown) was performed on all the algal data in Table 4 . In this case the total grazers, the covariate, was found to be non-significant i.e., the changes in the algal component was attributable to the direct effects of turbulence alone. Ammonia concentrations were similar for all rates of water turnover and turbulence (Table 4), although all concentrations were significantly lower than the dock.

\section{Experiment 4}

The individual means for total grazers, chlorophyll $a$, algae, productivity and ammonia at two levels of turbulence and three levels of benthic surface area are presented in Table 5. As with the previous experiment, no significant interaction term was found for any of the variables measured, thus, allowing a clear interpretation of the differences in the main factors of turbulence and benthic surface area. Because of the lack of interaction, this experiment was a repeat of the main effects of turbulence. As in Experiment 3, the mean density of total grazers increased by a factor of two as the turbulence went to zero (Table 5). The same results were found when the total grazers

Table 5

Comparisons of mean densities, concentrations or rates of total grazers (no. individuals $\cdot \mathbf{1}^{-1}$ ), chlorophyll $a\left(\mu \mathrm{g} \cdot 1^{-1}\right)$, algae (cells $\left.\cdot \mathrm{ml}^{-1}\right)$, productivity $\left(\mathrm{mg} \mathrm{C} \cdot \mathrm{m}^{-3} \cdot \mathrm{h}^{-1}\right.$ ) and ammonia ( $\mu \mathrm{g}$ at $\left.\mathrm{N} \cdot \mathrm{1}^{-1}\right)$ for different benthic surface areas $\left(\%\right.$ of $\left.169 \mathrm{~cm}^{2}\right)$ and turbulence levels (paddle size)

\begin{tabular}{|c|c|c|c|c|c|}
\hline Criteria & Turbulence & \multicolumn{3}{|c|}{ Benthic surface areas } & $X^{*}$ \\
\hline \multirow[t]{2}{*}{ Total grazers } & $\begin{array}{l}0 \\
1\end{array}$ & $\begin{array}{l}51.4 \\
26.9\end{array}$ & $\begin{array}{l}28.4 \\
16.6\end{array}$ & $\begin{array}{l}25.1 \\
11.8\end{array}$ & $\begin{array}{l}35.0 \\
18.4\end{array}$ \\
\hline & $\bar{X} *$ & 39.2 & 22.5 & 18.5 & \\
\hline \multirow[t]{2}{*}{ Chlorophyll a } & $\begin{array}{l}0 \\
1\end{array}$ & $\begin{array}{l}4.32 \\
5.49\end{array}$ & $\begin{array}{l}5.83 \\
7.56 \\
\end{array}$ & $\begin{array}{l}6.15 \\
8.53 \\
\end{array}$ & $\begin{array}{l}5.43 \\
7.19 \\
\end{array}$ \\
\hline & $\bar{X} *$ & 4.91 & 6.70 & 7.34 & \\
\hline \multirow[t]{2}{*}{ Algae } & $\begin{array}{l}0 \\
1 \\
\end{array}$ & $\begin{array}{l}1401 \\
3707\end{array}$ & $\begin{array}{l}2499 \\
7081 \\
\end{array}$ & $\begin{array}{l}1542 \\
7680 \\
\end{array}$ & $\begin{array}{l}1814 \\
6156 \\
\end{array}$ \\
\hline & $\bar{X}^{*}$ & 2554 & 4790 & 4611 & \\
\hline \multirow[t]{2}{*}{ Productivity } & $\begin{array}{l}0 \\
1 \\
\end{array}$ & $\begin{array}{l}2.40 \\
6.10 \\
\end{array}$ & $\begin{array}{l}2.66 \\
7.34 \\
\end{array}$ & $\begin{array}{l}3.92 \\
6.09 \\
\end{array}$ & $\begin{array}{l}2.99 \\
6.51 \\
\end{array}$ \\
\hline & $\overline{\mathrm{X}^{*}}$ & 4.25 & 5.00 & 5.01 & \\
\hline \multirow[t]{2}{*}{ Ammonia } & $\begin{array}{l}0 \\
1 \\
\end{array}$ & $\begin{array}{r}0.35 \\
0.34 \\
\end{array}$ & $\begin{array}{l}0.49 \\
0.53 \\
\end{array}$ & $\begin{array}{l}0.52 \\
0.37 \\
\end{array}$ & $\begin{array}{l}0.45 \\
0.41 \\
\end{array}$ \\
\hline & $\overline{\mathrm{X}} *$ & 0.35 & 0.51 & 0.45 & \\
\hline
\end{tabular}


were partitioned into Acartia clausi adults, juveniles and nauplii and barnacle larvae (not shown). However, accompanying the density increase with decreasing turbulence was a major shift in the age structure of Acartia clausi, the numerically dominant zooplankter. In the tanks with no paddle the ratio of juvenile Acartia to nauplii was over $300 \%$ greater than the tanks with one stirring paddle (Table 6). Computation of these ratios for Experiment 3, where turbulence was varied similarly, revealed no significant shifts in age structure compared to the bay where the density of nauplii exceeded that of the juveniles. A rather surprising result was the inverse relationship of total grazers and benthic surface area. That is, the grazers were being "predated" by the benthic-sediment system.

Table 6

Comparisons of mean juvenile to nauplii ratios for Acartia clausi exposed to different benthic surface areas $\left(\%\right.$ of $\left.169 \mathrm{~cm}^{2}\right)$ and turbulence

\begin{tabular}{|c|c|c|c|c|c|}
\hline & & \multicolumn{2}{|c|}{$\begin{array}{c}\text { Benthic surface area } \\
\left(\% \text { of } 169 \mathrm{~cm}^{2}\right)\end{array}$} & \multirow[b]{2}{*}{1} & \multirow[b]{2}{*}{$\bar{X} *$} \\
\hline & & 0 & 0.5 & & \\
\hline \multirow[t]{2}{*}{$\begin{array}{l}\text { Turbulence } \\
\text { (Paddle size) }\end{array}$} & $\begin{array}{l}0 \\
1\end{array}$ & $\begin{array}{l}2.97 \\
0.77\end{array}$ & $\begin{array}{l}4.11 \\
0.85\end{array}$ & $\begin{array}{l}1.82 \\
0.78\end{array}$ & $\begin{array}{l}2.97 \\
0.80\end{array}$ \\
\hline & $\overline{\mathrm{X}}^{*}$ & 1.87 & 2.48 & 1.30 & \\
\hline
\end{tabular}

The structure and function of the algal community again showed a significant but opposite relationship to that observed for the total grazers; namely, as turbulence decreased the algae decreased (Table 5). However, as in the previous experiment only this time with the variable benthic surface area, no significant differences between the means for chlorophyll $a$, algal density and productivity over the different levels of benthic surface area were found. Analysis of covariance (not shown) indicated that changes in the algal component under different turbulence regimes was due to the direct effect of the turbulence rather than the indirect effect of grazing by the zooplankton. Ammonia concentrations were similar for all turbulence rates and levels of benthic surface area (Table 5) although all concentrations were significantly lower than at the dock.

\section{Experiment 5}

The repeat of the winter light experiment (Experiment 1) during the summer (see Table 1 for light regimes) revealed a different response to light. Linear regressions on $\log$ transformed chlorophyll a data to Day 10 (this time period was chosen because it preceded the rapid decreases in algae for both experiments) for the two experiments were found to be significantly different from each other. The untransformed data is presented in Figure 4. Thus, the sensitivity to light from winter to summer decreased 
as seen by chlorophyll $a$ and algal density (not shown). This decrease occurred despite the order of magnitude decrease in total grazing pressure, assuming the observed density changes in total grazers are directly related to grazing during this period (Table 3 ). It would appear that the seasonal algal response to different light regimes cannot be attributed to seasonal changes in grazing pressure.

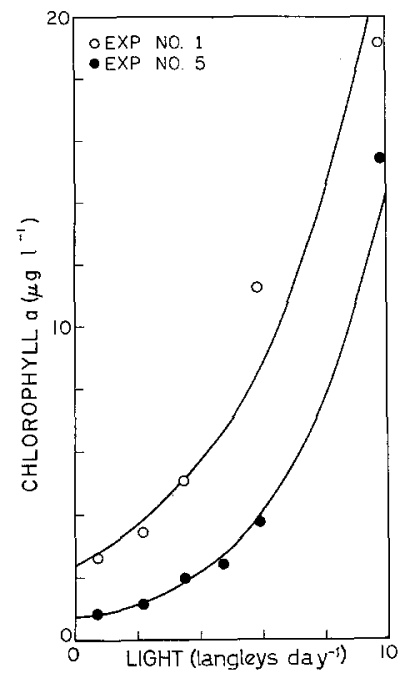

Fig. 4: Mean concentrations of chlorophyll a $\left(\mu \mathrm{g} \mathrm{l}^{-1}\right)$ as a function of light (langleys day $\left.{ }^{-1}\right)$ at day 10 during late winter and early summer in laboratory systems

The ammonia concentrations at the start of both light experiments were statistically the same (not shown). If ammonia is related to total nutrients, then the observed differences in algal response between the two experiments cannot be attributed to initial differences in nutrient levels.

No significant differences were found between the tanks whose fixed light regime equaled the mean for the fluctuating tanks (not shown); this result is equal to that found in Experiment 1.

\section{Table 7}

Seasonal changes in the mean benthic oxygen uptake $\left(\mathrm{mg} \mathrm{O} \mathrm{O}_{2} \cdot \mathrm{m}^{-2} \cdot \mathrm{h}^{-1}\right)$ and ammonia release $\left(\mu \mathrm{g}\right.$ at $\left.\mathrm{N} \cdot \mathrm{m}^{-2} \cdot \mathrm{h}^{-1}\right)$ for laboratory box cores $\left(169 \mathrm{~cm}^{2}\right)$

\begin{tabular}{|lcccccc|}
\hline \multicolumn{2}{r}{ Experiment No. } & 1 & 2 & 3 & 4 & 5 \\
& Season & $1 \sqrt{2}-2 / 23$ & $2 / 24-3 / 29$ & $4 / 6-5 / 6$ & $5 / 13-6 / 14$ & $6 / 29-7 / 15$ \\
\hline Oxygen & $\overline{\mathrm{X}}$ & 8.37 & 10.87 & 22.03 & 27.46 & 29.99 \\
uptake & $\mathrm{S} \overline{\mathrm{x}}$ & 0.37 & 0.60 & 0.92 & 3.67 & 1.82 \\
& $\mathrm{n}$ & 67 & 24 & 27 & 8 & 59 \\
Ammonia & $\overline{\mathrm{X}}$ & 9.51 & 12.48 & 44.8 & 89.56 & 119.50 \\
release & $\mathrm{S} \overline{\mathrm{x}}$ & 1.16 & 2.73 & 5.29 & 11.69 & 9.06 \\
& $\mathrm{n}$ & 56 & 24 & 27 & 12 & 59 \\
\end{tabular}


We were unable to detect significant treatment effects within all experiments on benthic oxygen uptake and ammonia flux. However, temporal increases (Table 7) similar to that found in previous in situ studies (Nixon et al., 1976) were observed.

Phytoplankton identifications showed no significant structural shift for any of the experimental treatments.

\section{Field $S t u d y$}

When we regressed at on moment in time (7/29/76) the dock total grazers and algal density against the mean for the area of W. Passage sampled, a significant linear relationship was found. The regression equation for each variable was: $\bar{x}$ density of W. Passage total grazers $=5.995+0.972$ ( $\overline{\mathrm{x}}$ dock density) and $\overline{\mathrm{x}}$ density of W. Passage algae $=226.404+279(\bar{x}$ dock density $)$. If one looks at the slopes of these equations as a measure of agreement between the dock and W. Passage, a slope of 1 being best agreement ignoring the intercept value, one sees that the dock follows W. Passage very well for total grazers but over estimates the algal density by a factor of 4 .

\section{DISCUSSION}

In this study we maintained in the laboratory replicate samples of a marine system in which we attempted to simulate the behavior of a large scale natural marine system. This experimental simulation required estimates and/or assumptions for the various physical factors of the natural system (e.g., turbulence and light, respectively) being simulated. We compared biological responses of the laboratory systems exposed to our best estimates for natural physical inputs with the responses actually exhibited by the natural ecosystem. At the same time, we adjusted the physical factors away from our best estimates in a separate series of identical laboratory systems. By performing these additional experiments, we were able to determine whether the ability of our laboratory systems to track the large scale system improved. It also told us the degree to which these factors influence the biological response within the laboratory systems and by inference in the large scale field system. As will be seen below, this experimental approach also enabled us to test the validity of some of our assumptions independently of field comparisons.

Interpretation of the results of these five experiments was made somewhat easier because (a) there was no treatment interaction between any of the factors tested and (b) the phytoplankton and zooplankton levels (Experiments $3 \& 4$ ) were found to be statistically independent of one another. Therefore, we were able to independently observe and assess the response of the phytoplankton and zooplankton to each factor tested.

The algal component in our laboratory systems was consistently greater than the dock from late winter to early summer (Table 3). If the dock underestimated the mean for the West Passage, then the algal increases could be explained. However, from the one field study done in July the opposite result occurred, namely the dock overestimated the West Passage by a factor of four. Future studies must be performed to 
verity this result for other seasons of the year. Assuming the algal density at the dock is equal to or greater than West Passage for Experiments 2 through 4, then we are confronted with developing a mechanism to explain the algal increase observed in our experimental systems.

It was initially suspected that the excessive algal densities might be due to the fact that the laboratory turbulence structure prohibited natural removal by settling. This, however, appears unlikely as the removal of algae by settling, at a rate of 0 to $6 \mathrm{~m} /$ day, for diatoms in the field (Smayda, 1970), would not nearly account for the algal increases observed in the laboratory.

Since the mean density of total grazers in our laboratory system and field were equal, the observed algal increases cannot be attributed to the lack of grazing assuming the zooplankton function similarly in our laboratory systems and the field.

Turbulence and light intensity were the only two physical factors tested that exhibited any influence on algal density. The level of turbulence simulated in the experimental systems (one paddle configuration) was based upon direct measurements made in the field. Therefore, we have no reason to suspect that this level of the turbulence was too high. It should be noted, however, that our studies indicate that turbulence does exhibit a significant effect on algal growth. Smayda (1957) concluded that algal increases observed following storms was due to nutrient increases. The results of our studies indicate that turbulence, also associated with storms could be a contributing factor, as well as nutrient levels, in controlling algal densities.

The light regime used in this study was based not only upon measurements of light quantity and quality taken in the field, but on a number of assumptions as well. We assumed, for example, that exposure to the mean light intensity for the $8.5 \mathrm{~m}$ water column would have the same effects on the phytoplankton as exposure to the instantaneous light intensity found at each depth for a transient period of time. Such an assumption may not be correct. The growth rate of algae in a light regime fluctuating from inhibitory intensities found at the surface and insufficient intensities at the bottom may be less than the growth rate realized when algae are exposed to the mean light regime. We did look at one aspect of this problem when we fluctuated the light regime. No significant differences were found when we compared the algal response in the fluctuating and fixed light experiments. The same result was found in a terrestrial study using more than one rate of change in light (McCree \& Loomis, 1969). However, it should be indicated that the range of fluctuating intensities in our experiments did not include surface inhibitory intensities.

One final explanation for the higher algal concentrations in the laboratory systems as compared to the field system was the absence of large grazing macrofauna such as fish, large bivalves and ctenophores greater than $1 \mathrm{~mm}$. Algal increases did occur not only during the warmer months of the year but also during the late winter and early spring when these organisms were either absent or grazing at extremely low rates. However, the conclusion that grazing macrofauna are unimportant in our tanks and therefore, the natural system does not necessarily follow. Since the lack of grazing macrofauna as well as inappropriate light could both account for the higher algal densities in our tanks, it is not possible to access the relative importance of grazing macrofauna at this time. 
The densities of total grazers, primarily zooplankton in our control systems equalled statistically that measured in West Passage. These results suggest that the various experimental conditions existing in our tanks were responsible for the observed zooplankton dynamics. Therefore, scrutiny of these conditions enable us to draw inferences about mechanisms controlling pelagic grazers in the field. Variations in benthic surface area and water turbulence revealed that both variables independently and directly affected the densities of total grazers. With respect to the former, however, we know of no organisms in the benthic subsystem which feed upon pelagic zooplankton. Therefore, the apparent zooplankton "predation" by the benthos was probably due to physical entrapment by the sediment. We do not know at the present time whether this result is real or an experimental artifact. Future studies need to determine the rate and manner in which the water column interfaces with sediments in the field. At field turbulence levels, we do know, however, that when sediments were removed from the experimental system the zooplankton levels more closely approached the mean density for West Passage (Tables 3, 5). This lends credence to the view that the observed relationship between benthic surface area and total grazers was an experimental artifact. The responses of zooplankton to water turbulence are not artifacts because direct measures rather than assumptions, as was made with interfacing the benthic and pelagic phases, were the bases of the simulation. In Experiment 4, the mean density of total grazers with one paddle and no benthos was 26.9 which was statistically equal to 20.9 , the mean for West Passage. However, when the water turbulence was reduced the density of total grazers significantly increased by almost $200 \%$ in thirty days; the same result occurred in Experiment 3 . Therefore, turbulence is a major controller of grazers in our laboratory systems. This result assumes added significance since we excluded large predatory macrofauna, such as fish or ctenophores, greater than $1 \mathrm{~mm}$ from our systems. The ability to follow the field system without the presence of such organisms implies that zooplankton predators play a relatively minor role in the field. The results of another study support the view that turbulence, not predatory macrofauna, control zooplankton populations in the field. Takihashi et al. (1975) encapsulated an oceanic system in a large plastic bag. Planktonic communities as well as large ctenophores, known predators of zooplankton, were present in the bags (P. Koeller, personal communication). No turbulence was simulated in these bags. If macrofauna control the density of zooplankton, then one would expect the zooplankton in the bags to be numerically equal to the surrounding water assuming the latter is representative of the oceanic system being simulated. However, if turbulence rather than macrofauna control zooplankton, then one would expect the zooplankton density to increase dramatically with respect to the density outside the bags as was observed in our experiments. The latter result occurred in that large densities of zooplankton were observed in the bags. Based upon the above, we conclude that zooplankton densities in the field are controlled predominantly by the abiotic factor, water turbulence. Such a conclusion is constrained by the algal concentrations existing in this study.

A five-fold decrease in water turnover had no significant effect on the density of zooplankton. That is, the sensitivity of zooplankton to variations in water turnover 
around 35 days was low. Thus, the error resulting from a water turnover time greater than that existing in the field system was negligible.

This study has shown that the methods and levels chosen for scaling physical and biotic variables were critical to the behavior of our laboratory systems, and thus, to the ability of these systems to mimic the field system. Previous studies (Odum \& Chestnut, 1970; Cooper \& Copeland, 1973; Odum et al., 1963) have failed to quantitatively define the large scale field system being simulated. As a result, such studies were unable to test whether the scaling of physical and biotic variables were sufficient. If the correspondence between the experimental and field system in the unperturbed state is subject to question, then the validity of the observed behavior of the experimental systems in the perturbed state is also subject to question. We suggest that before perturbation experiments are performed, it is essential to demonstrate in the unperturbed state that the small scale experimental systems and the large scale field systems are elements of the same set.

Acknowledgements. We would like to express our appreciation for assistance in this study to D. Winslow, D. Dillman, P. Roques, J. Kelly and P. Murphy.

\section{LITERATURE CITED}

Anonymous, 1959. Contamination dispersion in estuaries, Narragansett Bay. Hydraulic model investigation. U.S. Army Corps of Engineers. U.S. Army Eng. Water ways Expt. Sta. Misc. Pap. 2, 1-332.

Bernier, C. J., 1962. Measurement techniques for the radient energy requirements of growing plants. Natn. Tech. Conf. of the Illuminating Eng. Soc., Dallas, Texas, 5 pp.

Cooper, D. C. \& Copeland, B. J., 1973. Responses of continuous-series estuarine microcosystems to point-source input variations. Ecol. Monogr. 43, 213-236.

Hale, S., 1974. The role of benthic communities in the nutrient cycle of Narragansett Bay. M.A. thesis, Univ. of Rhode Island, Kingston, 123 pp.

Hicks, S. D., 1959. The physical oceanography of Narragansett Bay. Limnol. Oceanogr. 4, 316-327.

Jerlov, N. G., 1968. Optical oceanography. Elsevier, Amsterdam, 194 pp.

McCree, K. S. \& Loomis, R. S., 1969. Photosynthesis in fluctuating light. Ecology 50, 422-428.

Nixon, S. W., Oviatt, C. A., Hale, S. S., 1976. Nitrogen regeneration and the metabolism of coastal marine bottom communities. Brit. ecol. Soc. Symp. Decomp., Coleraine, N. Ireland, April 1975. 14 pp.

Odum, H. T. \& Chestnut, A. F., 1970. Entichment of experimental estuarine ponds with sewage. A. Rep. Office Sea Grant, U.S. Dept. Comm., NOAA. 1, 1-364.

- Silver, W. L., Beyers, R. J., Armstrong, N., 1963. Experiments with engineering of marine ecosystems. Publs Inst. mar. Sci., Univ. Texas 9, 373-403.

Oviatt, C. A., Perez, K. T. \& Nixon, S. W., 1977. Multivariate analysis of experimental marine ecosystems: results for Narragansett Bay. Helgoländer wiss. Meeresunters. 30, 30-46.

Pratt, D. M., 1965. The winter-spring diatom flowering in Narragansett Bay. Limnol. Oceanogr. 10, 173-184.

Smayda, T. J., 1957. Phytoplankton studies in. Lower Narragansett Bay. Limnol. Oceanogr. 2, 342-359.

- 1970. The suspension and sinking of phytoplankton in the sea. Oceanogr. mar. Biol. 8, 353-414.

Snedecor, G. W. \& Cochran, W. G., 1967. Statistical methods. Iowa State Univ. Press, Ames, Iowa, $593 \mathrm{pp}$. 
Solorzano, L., 1969. Determination of ammonia in natural waters by the phenolhypochlorite methods. Limnol. Oceanogr. 14, 799-801.

Spalding, M. \& Swanson, G., 1975. Tidal currents in Narragansett Bay. Mar. Tech. Rpt. Univ. of Rhode Island 56, 1-40.

Strickland, J. D. H. \& Parsons, T. W., 1968. A practical handbook of seawater analysis. Bull. Fish. Res. Bd Can. 167, 311 pp.

Takahashi, M., Thomas, W. H., Seibert, D. L. R., Beers, J., Koeller, P. \& Parsons, T. R., 1975. The replication of biological events in enclosed water columns. Arch. Hydrobiol. 76 (1), 5-23.

Utermöhl, H., 1931. Neue Wege in der quantitativen Erfassung des Planktons. Verh. int. Verein. theor. angew. Limnol. 5, 567-595.

Walters, C. J. \& Efford, I. E., 1972. Systems analysis in the Marion Lake IBP Program. Oecologia 11, 33-44.

Winer, B. J., 1971. Statistical principles in experimental design. McGraw-Hill, New York, $672 \mathrm{pp}$.

First author's address: K. T. Perez

U.S. Environmental Protection Agency

Environmental Research Laboratory

South Ferry Road

Narragansett, Rhode Island 02882

USA 